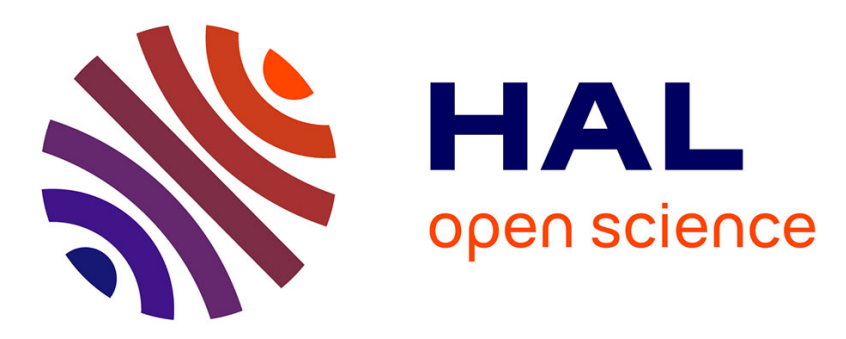

\title{
The consumption of bone powder in the Early Neolithic societies of Southeastern Europe: evidence of a diet stress?
}

Julien Vieugué, Laure Salanova, Martine Regert, Sigrid Mirabaud, Anne-Solenn Le Hô, Eric Laval

\section{To cite this version:}

Julien Vieugué, Laure Salanova, Martine Regert, Sigrid Mirabaud, Anne-Solenn Le Hô, et al.. The consumption of bone powder in the Early Neolithic societies of Southeastern Europe: evidence of a diet stress?. Cambridge Archaeological Journal, 2015, 25 (2), pp.495-511. 10.1017/S0959774314001048. hal-01310870

\section{HAL Id: hal-01310870 \\ https://hal.science/hal-01310870}

Submitted on 15 May 2018

HAL is a multi-disciplinary open access archive for the deposit and dissemination of scientific research documents, whether they are published or not. The documents may come from teaching and research institutions in France or abroad, or from public or private research centers.
L'archive ouverte pluridisciplinaire HAL, est destinée au dépôt et à la diffusion de documents scientifiques de niveau recherche, publiés ou non, émanant des établissements d'enseignement et de recherche français ou étrangers, des laboratoires publics ou privés. 


\title{
The Consumption of Bone Powder in the Early Neolithic Societies of Southeastern Europe: Evidence of a Diet Stress?
}

\author{
Julien Vieugué, Laure Salanova, Martine Regert, Sigrid Mirabaud, \\ Anne-Solenn Le Hô \& Éric Laval
}

\begin{abstract}
Research performed on Early Neolithic ceramic assemblages from southwestern Bulgaria has revealed that several categories of pottery were used for the preparation of foodstuffs. One particular type of beige residue has been identified on the inner surface of ceramic vessels from several sites. Chemical analyses of mineral residues, combined with the stylistic characteristics of ceramic vessels, have shown the consumption of bone powder. This consumption, far from being anecdotal, raises several questions regarding the diet behaviour of the earliest Neolithic communities in the Balkans, which have obviously sought a complementary source of calcium. Would the dietary transition at the beginning of the Neolithic period correspond to a diet stress?
\end{abstract}

\section{Introduction}

The Neolithic introduces new dietary practices, related to the development of agriculture and animal husbandry, as well as the emergence of pottery. This transition occurs gradually in the Near East between the ninth and the seventh millennia cal. BC. From this region, new culinary habits - namely the consumption of domesticated animal and plant species in or on ceramic plates - will spread into Europe during the seventh and sixth millennia cal. BC.

The factors which are the cause of these changes remain to be identified. As climatic and environmental variations could not have been the only factors to explain such a human evolution, several scholars have oriented the debate to other directions: change in symbolic, cultural and cognitive values (Cauvin 1997; Jongsma \& Greenfield 2002; Watkins 1992;); new techniques of storage and of accumulating wealth (Testart 1982); new tradition of food production (e.g. Helmer et al. 2005; Larson et al. 2007; Vigne 2008; Evershed et al. 2008; Marom \& Bar-Oz 2009; Tresset et al. 2009; Edwards et al. 2011).

Research performed on the main Early Neolithic pottery assemblages from southwestern Bul- garia (6100-5600 cal. вC) has revealed that a diversity of manufacturing techniques, decorative traditions and functions were present since the very onset of the Neolithic in the region (Salanova 2009; Salanova et al. 2010; Salanova et al. in press). Use-wear and residue analysis has demonstrated that several categories of vessels were used in the preparation of foodstuffs (Vieugué et al. 2008; Vieugué 2014; forthcoming). One particular type of beige residue has been found on the ceramic vessels from several sites, providing evidence for the consumption of bone powder. This preparation, far from being anecdotal within the pottery assemblages, bears many implications with regards to the diet patterns of the earliest Neolithic communities in the region. More generally, it raises questions whether the Neolithic way of life was adopted due to a diet stress.

\section{The first Neolithic communities from Bulgaria \\ Context of emergence \\ In the debate concerning the emergence of the $\mathrm{Ne}$ - olithic in Europe, Bulgaria has an essential role, lo- cated at the centre of three zones where the Neolithic}


appears previously - Anatolia, Greece and the Pontic Steppes (Perlès 2001; Reingruber \& Thissen 2005; Kotova 2009) - and of a fourth in which the Neolithic appears shortly afterwards - the Italo-Adriatic region (Guilaine \& Cremonesi 2003; Forenbaher \& Miracle 2005; Tiné 2009). The collection of data on the evolution of ecosystems is still weak in Bulgaria, and generally absent from syntheses that concern the whole of Europe, whether they be economic (for example Vigne 2003), climatic (Berger \& Guilaine 2009) or bio-anthropological (Deguilloux et al. 2012). The processes that drove the spread of the Neolithic and the transformation of local communities remain little discussed, but some recent researches have proposed a model from pottery analysis (Salanova et al. in press).

These researches have begun within the framework of a French-Bulgarian programme started in 1986 on the site of Kovatchevo (southwestern Bulgaria). The excavations have allowed the discovery of the most complete stratigraphical sequence $(3 \mathrm{~m}$ of thickness) for the Early Neolithic of the Southern Balkans while revealing the age of the first Neolithic occupations in the region (c. 6100 cal. BC) (LichardusItten et al. 2002). Within this programme, pottery held an important role as it makes up 23 out of the 45 tonnes of all artefacts recorded during the excavation. The complete analysis of pottery was performed by one of us who has developed a study method of huge ceramic assemblages (Salanova 2009; Salanova et al. 2010). The assemblage is characterized not only by its size, but also by a good state of preservation of the vessels and an important diversity of fired clay containers (Salanova et al. 2010; in press). It is composed of every type of vessel that one could expect to find at the Neolithic period, from very small pots to large storage vessels (Salanova 2009). A limited quantity (3$4 \%$ ) of decorated pottery, mainly painted in white on red, as was usual during the Balkan Early Neolithic, has also been discovered (Salanova 2009). The quality of the vessels, as well as their huge quantity, demonstrates that they were the products of experienced potters and without a doubt would have been integrated into the activities of everyday life. Such a statement is equally valid for the other Early Neolithic sites studied (Fig. 1).

Concerning the methods for pottery analyses, stylistic approaches have been used to create the chronological framework from decorative patterns, which evolves quite rapidly over time, particularly with regards to synchronising the periodization of pottery assemblages at the scale of the Struma River Valley as a whole (Salanova 2011). However, technological and functional approaches have been performed in order to identify accurately the different social and cultural groups who lived in southwestern Bulgaria during the Early Neolithic (Salanova et al. 2010; Vieugué 2010). The functional analysis of pottery has consisted in combining the typometric characteristics (shape, size, and volume) and the use-wears (residues and attritions) of ceramic vessels (Vieugué 2010; 2014). The study was carried out on a statistically significant number of artefacts from the ceramic assemblages of each settlement. The sampling was defined from the general characterization of pottery productions that has allowed us to determine the most diagnostic remains regarding the function of ceramic vessels (Salanova et al. 2010; in press). The research has thus taken into account: (i) all the pottery that has at least a half profile; (ii) a group of pottery sherds selected according to chronological and spatial issues. In total, 1696 ceramic vessels and 192,616 sherds were the subject of thorough examination. The detailed observation of use-wears has particularly revealed the recurrent presence of residues adhering to the inner surface of ceramic vessels.

\section{From pottery function to culinary habits of first farmers from Bulgaria}

The thorough study of the residues identified on the surface of the earliest ceramic vessels from Bulgaria had two main objectives. The first was to obtain information about the foodstuffs consumed by the first Neolithic people of the region. With some exceptions, the mineral and organic residues represent the remains of the original content of fired clay containers (Evershed 2008; Regert et al. 2008). Through various analytical techniques, it is possible to identify different chemical compounds whose association is characteristic of the natural origin of substances processed inside the ceramic vessels (Heron \& Evershed 1993; Evershed et al. 1997). Subcutaneous animal fats (for example Evershed et al. 1997; Salque et al. 2012), dairy products (Copley et al. 2005; Mirabaud et al. 2007), beeswax (Regert et al. 2001; Decavallas 2007), salt (Weller 2000; Horiuchi et al. 2011), vegetable oils (Regert 2007) and marine substances (Craig et al. 2013) can thus be found inside Neolithic pottery. The presence of such raw materials within ceramic vessels allows the inference of some of the foodstuffs consumed by the prehistoric groups. If the identification of subcutaneous animal fats proves the consumption of meat, that of beeswax could suggest the consumption of honeys during the Neolithic (Regert et al. 1999; 2001).

The second objective was to obtain information about the preparation of foodstuffs within the first farming societies in Bulgaria. The visible residues on the surface of archaeological ceramic vessels are typically caused by carbonization of the original 


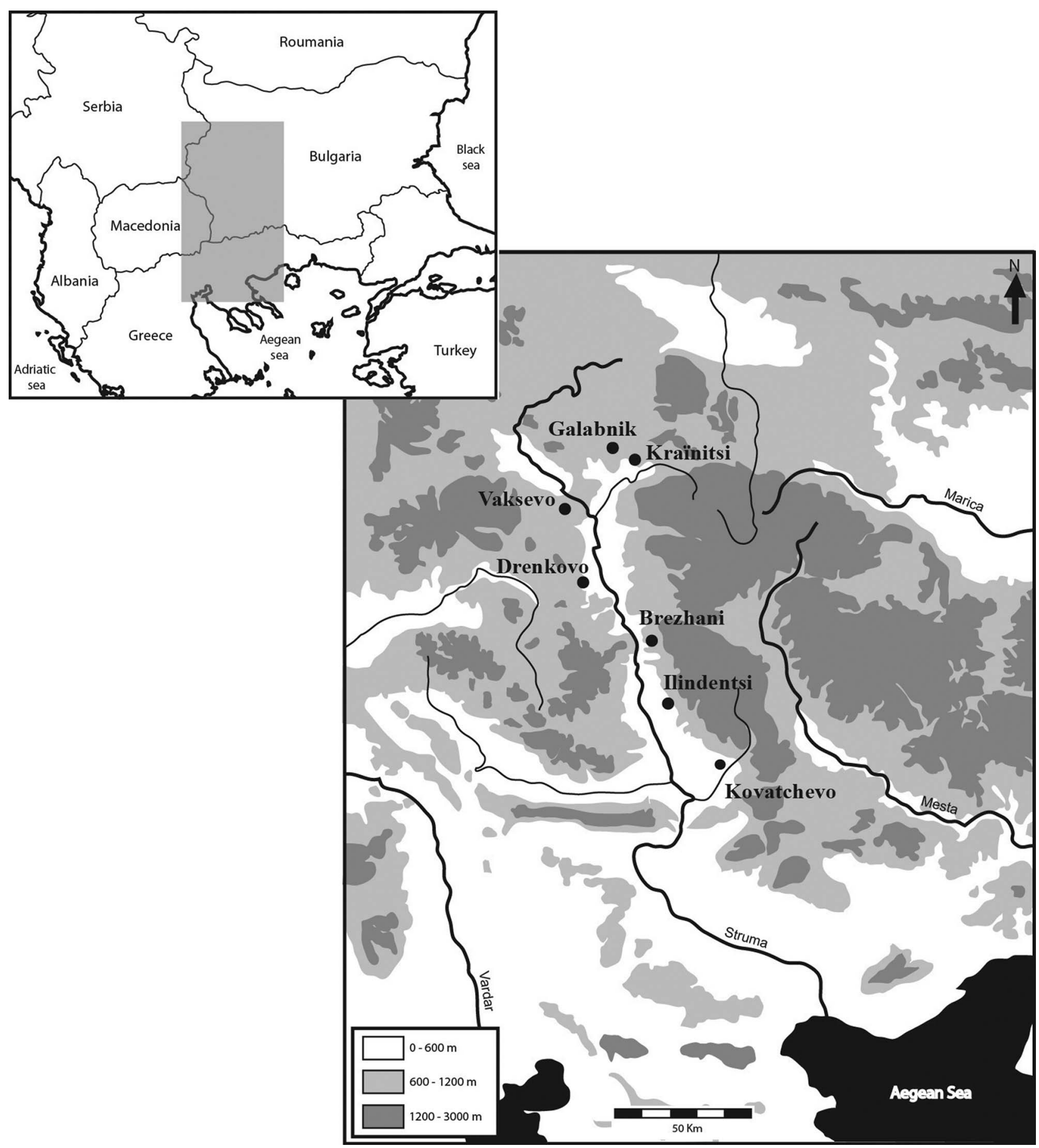

Figure 1. Location of the seven main Early Neolithic settlements in the Struma River Valley (southwestern Bulgaria).

content of fired clay containers (Skibo \& Blinman 1999). This carbonization occurs during the cooking of foodstuffs. Based on the distribution of residues developed on the inner surface of ceramic vessels, it is possible to specify the position of the pottery on a fire. For example, the cooking pots placed at the centre of hearths can be distinguished from those put at the periphery (Skibo 1992). This difference refers to various methods of food cooking. In this case, it lets us assume a faster or slower heating of foodstuffs consumed by the prehistoric groups (Martinez 1993). 

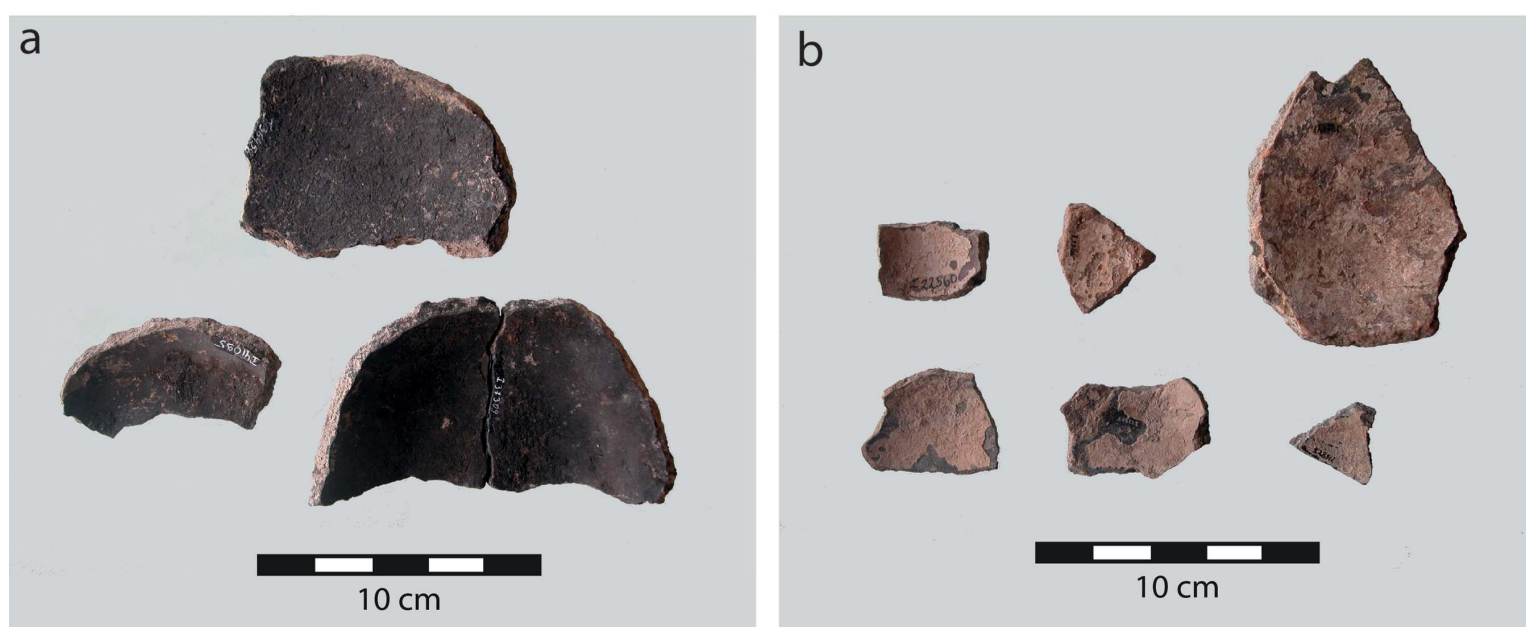

Figure 2. (Colour online) Typology of residues preserved in the ceramic vessels: (a) black residues; (b) beige residues.

By informing the consumed foodstuffs and the ways of food preparation, the analysis of the residues was likely to increase our knowledge about culinary practices within the first farming communities in Bulgaria.

\section{Materials and method: residues from the pottery content}

\section{Typology of residues}

The visible residues on the inner surface of the earliest ceramic vessels from Bulgaria can be grouped into two main categories (Fig. 2). The categories are distinguished by their colour, surface regularity, compactness, adherence, and specific extent.

The first category is composed of black pulverulent residues. They weakly adhere to the inner surface of ceramic vessels. Their upper surface is irregular and their extent is relatively limited. In Kovatchevo where the quantitative data are precise, carbonized residues account for 0.3 per cent of all pottery sherds. This percentage corresponds to about 1024 vessels if it refers to the counts that were performed on the decorated pottery from the site ( 3 per cent of pottery sherds $=10,238$ ceramic vessels) (Salanova 2009). These residues cannot be considered as an inner coating of ceramic vessels, because of their irregular surface and their limited extent (Mirabaud 2007). They obviously mark the original content of fired clay containers. The deposits from the first category correspond more to the archaeological food residues than adhesive substances, due to their dark black colour, porous structure and their limited adherence to the wall of the pottery (Regert 2007; Regert et al. 2008). They certainly result from the cooking of prehistoric foodstuffs. Despite the poor state of preservation of organic materials, animal fats have been identified from the residues of some ceramic vessels (Vieugué et al. 2009).

The second category is composed of dense beige residues that present a doughy aspect. These residues adhere more strongly to the inner surface of ceramic vessels. Their surface is generally smooth. They often cover a major part of the interior of ceramic vessels. These beige residues were not initially identified in the pottery because of their strong similarity to post-depositional calcareous concretions that regularly cover the surfaces and the edges of archaeological artefacts. Two complete vessels, showing beige residues that were confined to the inner surface, caught our attention and drove us towards conducting preliminary chemical analyses (Vieugué et al. 2009). The specific macroscopic characteristics (colour, adherence, density, surface regularity and extent) of beige residues found on the inner surface of ceramic vessels allowed us to distinguish them from taphonomic calcareous deposits. In Kovatchevo, such beige residues were identified on around 2 per cent of ceramic vessels (Table 1). Based on preliminary calculations, this percentage corresponds to at least 6820 vessels. Unlike the residues from the first category, the meaning of the deposits from the second class was much more ambiguous: are they the remains of a coating or a content of ceramic vessels? Three observations allowed us to rule out the first hypothesis. Firstly, the best-preserved beige residues marked a clear limit located toward the inner rim of ceramic vessels (Fig. 3). Such an interruption makes it difficult to justify the use of bone powder as an inner coating, because waterproofing would have been applied on all of the inner surface of ceramic vessels. Secondly, several pottery sherds showed superimposed layers of beige residues (Fig. 4). On the contrary, the application of an inner 
The Consumption of Bone Powder in the Early Neolithic Societies of Southeastern Europe

Table 1. Pottery that presented beige residues in comparison with the total of studied ceramic vessels.

\begin{tabular}{|l|l|l|l|}
\hline Sites & Numbers of pottery examined & Numbers of pots with beige residues & $\%$ \\
\hline Kovatchevo & 1079 vessels $+188,153$ sherds & 32 vessels +717 sherds & 2.96 \\
\hline Ilindentsi & 68 vessels +1654 sherds & 2 vessels +9 sherds & 2.94 \\
\hline Brezhani & 133 vessels +2809 sherds & 1 vessel +15 sherds & 0.75 \\
\hline Drenkovo & No quantitative study & Presence & indet. \\
\hline Vaksevo & 87 vessels & 2 vessels & 2.3 \\
\hline Kraïnitsi & 48 vessels & 1 vessel & 2.1 \\
\hline Galabnik & 281 vessels & 8 vessels & 2.8 \\
\hline Total & $\mathbf{1 6 9 6}$ vessels $+\mathbf{1 9 2 , 6 1 6}$ sherds & $\mathbf{4 6}$ vessels $+\mathbf{7 4 1}$ sherds & $\mathbf{2 . 3}$ \\
\hline
\end{tabular}

coating would have caused a unique layer inside the ceramic vessels (Mirabaud 2007). Thirdly, the beige residues were identified inside fired clay containers that were carefully slipped and polished. Such pottery was perfectly suitable for the storage of liquids without such a coating. It is therefore unlikely that the beige substance was applied to the inner surface of ceramic vessels in order to improve their waterproofing. While representing the content of pottery, the residues from the second category were similar to no type of deposits previously identified inside Neolithic ceramic vessels. Their visual characteristics allowed us to make no assumption as to the culinary or technical activity that may have caused the formation of beige residues on the inner surface of pottery.

This paper focuses on the second category of residues. In order to identify the substances preserved within the ceramic vessels, samples of pottery sherds were carried out and analysed on the ceramic vessels from the seven main Early Neolithic settlements of southwestern Bulgaria.

\section{Selection of archaeological samples}

The huge quantity of pottery sherds showing beige residues led us to select samples that were to be analysed. Samples were, on the one hand, collected on a group of encrusted fragments among the best preserved from each site. In this case, the pottery sherds, where the thick beige residue was not covered in taphonomic carbonate concretions, were favoured. The objective was to maximize the probability of identifying the materials that composed the archaeological residues while minimizing the bias introduced by post-depositional alterations. Samples were, on the other hand, collected on a set of ceramic vessels that present at least a half-profile. In this case, all the fired clay containers that showed a visible beige residue were sampled. The goal was to determine stylistic and technical characteristics of ceramic vessels that are associated with this type of atypical residue. In total, 77 samples were taken of the archaeological remains
Table 2. Number of analysed samples from the seven main Early Neolithic settlements in southwestern Bulgaria.

\begin{tabular}{|l|l|l|}
\hline Sites & Number of samples & Analytical techniques \\
\hline Kovatchevo & 46 & FTIR + SEM \\
\hline Ilindentsi & 5 & FTIR \\
\hline Brezhani & 3 & FTIR \\
\hline Drenkovo & 3 & FTIR \\
\hline Vaksevo & 12 & FTIR \\
\hline Kraïnitsi & 1 & FTIR \\
\hline Galabnik & 7 & FTIR \\
\hline Total & 77 & \\
\hline
\end{tabular}

(Table 2). They were performed according to the protocols established for amorphous residues (Charters et al. 1993; Regert 1998).

\section{Analytical methods}

The beige residues that adhered to the inner surface of pottery provided no indicative morphology of their natural origins. Their characterization therefore required chemical analyses (Evershed et al. 1992; Heron \& Evershed 1993). Chemical studies were carried out at the C2RMF laboratory in Paris (France).

Having no prior indication as to the nature of the beige substance that was preserved within the ceramic vessels, preliminary analyses were first carried out on all the archaeological samples using Fourier Transform Infrared Spectroscopy (FTIR). This analytical technique is particularly suitable for the identification of a large range of mineral and organic compounds (Regert et al. 2006a). The micro-samples ( 2 to $3 \mathrm{mg}$ of residue) were added to potassium bromide powder $(300 \mathrm{mg})$, before being ground and compressed into small pellets. The analyses were carried out by transmittance using a Perkin-Elmer Spectrum 2000 IRTF spectroscope. The signal was measured on a spectral range, from 4000 to $300 \mathrm{~cm}^{-1}$, at a resolution of $4 \mathrm{~cm}^{-1}$ and an accumulation of 15 scans. The preliminary characterization of 77 samples using FTIR was completed by their study using Scanning Electron Microscopy (SEM-EDS). This technique 

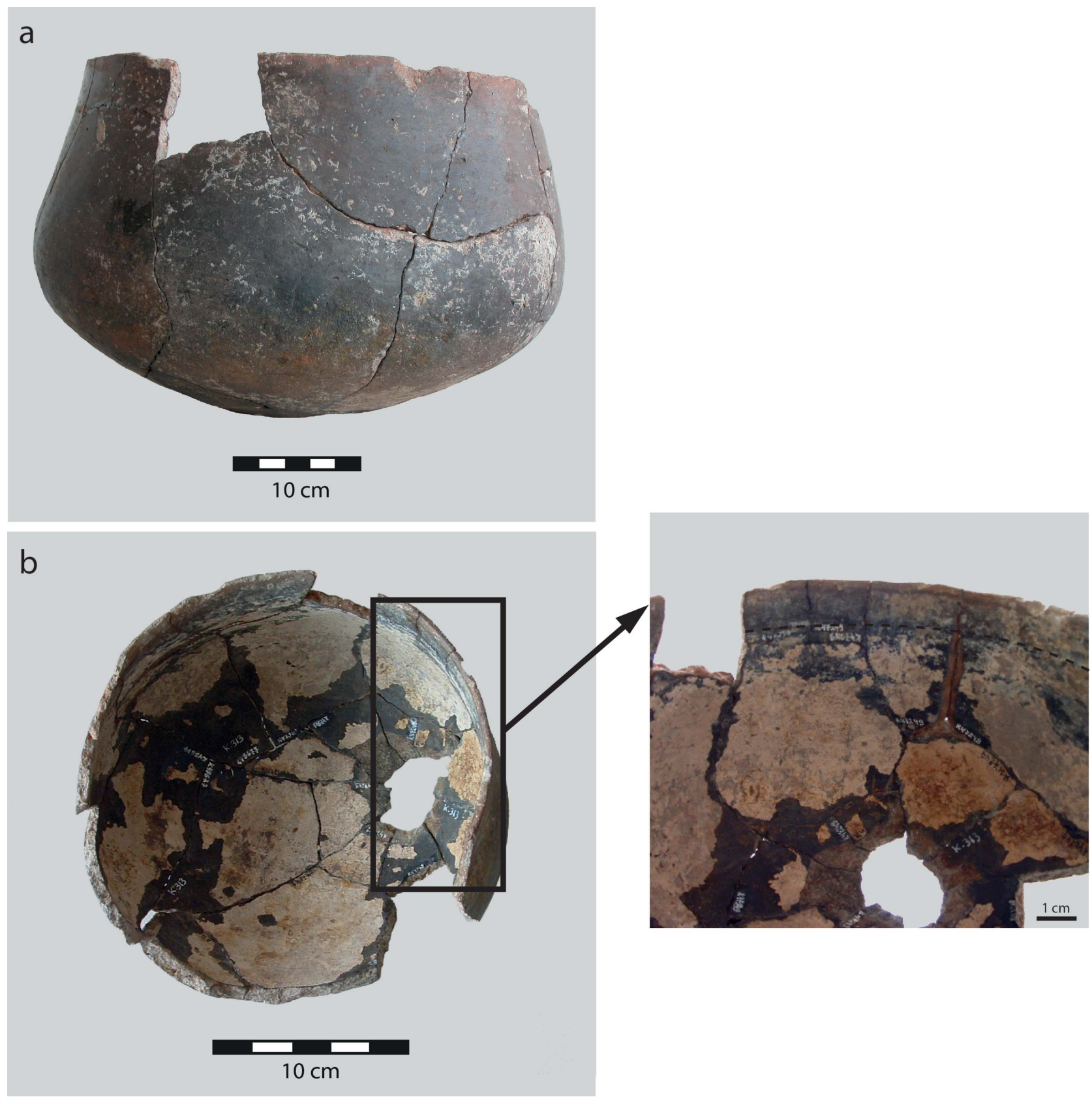

Figure 3. (Colour online) Outer surface (a) and inner surface (b) of a vessel containing bone powder. The clear limit of the beige residue that stops just below the rim shows the presence of pottery content.

offers not only the possibility to observe the mineral residues at a microscopic scale, but also to establish their chemical composition (Regert et al. 2006b). The samples were embedded in an Araldite resin, polished and metallized. The analyses were carried out using a JEOL JSM-840 type microscope equipped with an EDS Oxford detector. Measurements were taken at 20 $\mathrm{keV}$ with a current that was around $10^{-10}-10^{-9}$ amps.
These different analytical techniques provided spectral imprints that were characteristic of either the elementary or structural composition of the beige substance preserved in the pottery. The identification of the archaeological residues was established by comparing their spectral imprints with those obtained on artificially aged reference materials in the laboratory. 


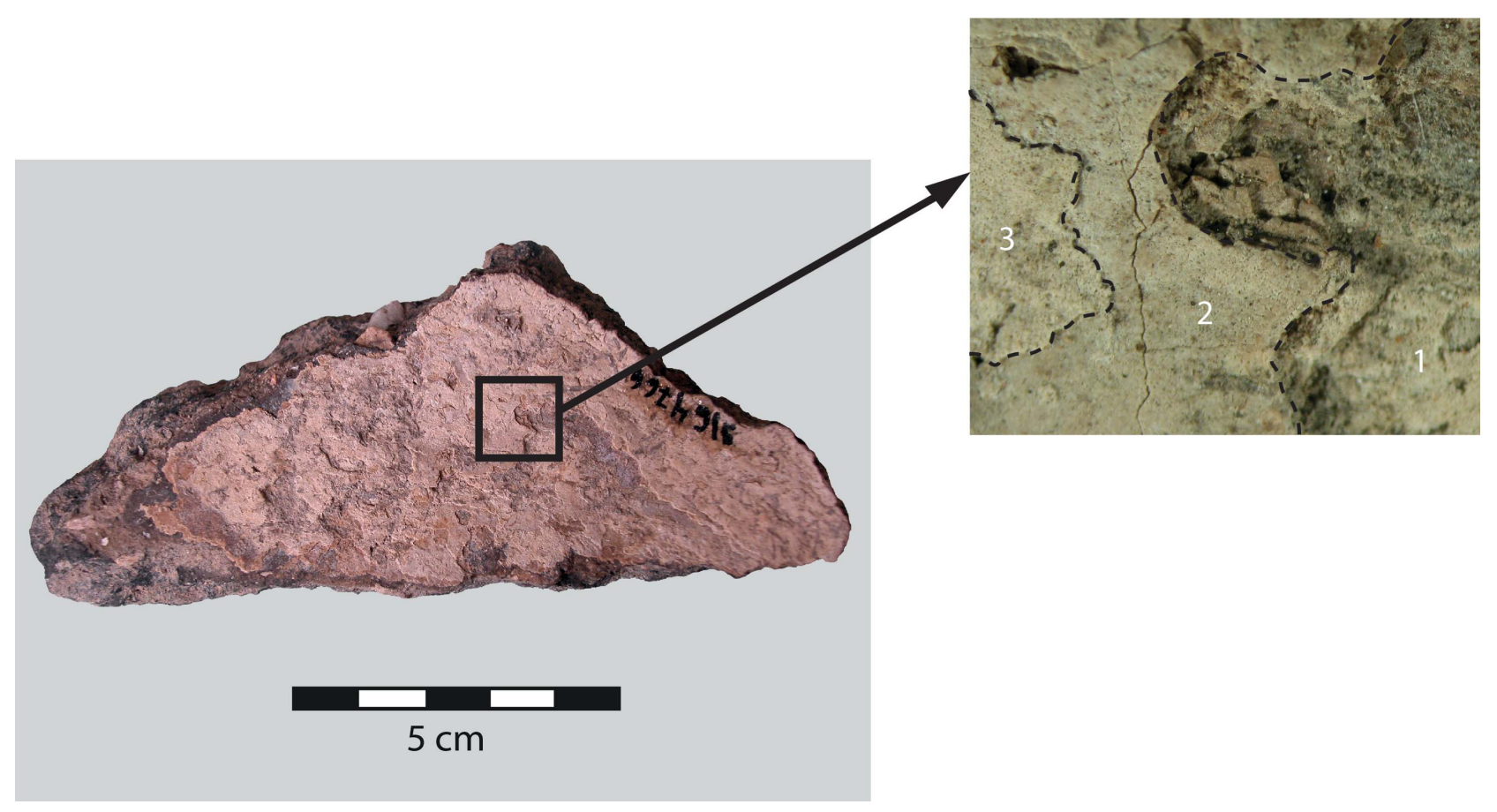

Figure 4. (Colour online) Superimposed layers of beige residue, bearing witness to the multiple use of a single vessel for the consumption of bone soup.

\section{Results: bone powder and Neolithic foodstuffs}

\section{Chemical identification of beige residues}

The analysis of beige residues using FTIR provided identical spectral imprints. These imprints show vibrational bands that are characteristic for carbonate $\left(\mathrm{CO}_{3}{ }^{2-}\right)$, phosphate $\left(\mathrm{PO}_{4}{ }^{3-}\right)$, and carbonyl $(\mathrm{CO})$ chemical bonds. Such a structural signature was similar to that obtained on prehistoric bones (Fig. 5) (Reiche et al. 2002). The characterization of the beige residues using SEM-EDS also shows identical spectra. The samples were mainly composed of Calcium (Ca) and Phosphorus (P). The association of these two compounds and their relative concentrations are characteristic of archaeological bone materials (Fig. 6) (Reiche et al. 2002; 2003). While the elemental composition of beige residues is extremely close to that of prehistoric bones, it differs substantially from the chemical imprints obtained on the carbonate concretions. Thus, Phosphorus $(\mathrm{P})$ that is strongly present within the beige residues is absent of taphonomic calcareous deposits. Silicon (Si) and Aluminium (Al) that are absent in the beige residues abound within carbonate concretions (Fig. 7). Furthermore, the surrounding sediments appear poor in phosphorus elements $(\mathrm{P})$, rich in Silicon ( $\mathrm{Si}$ ) and Aluminum (Al) (Brochier, pers. comm.). Unlike the carbonate concretions, beige residues are not the result of crystallization of the various components of archaeological sediments. They represent, obviously, the presence of bone materials within the earliest ceramic vessels from the Balkans.

Thorough observation of the beige residues using SEM-EDS revealed their strong homogeneity and density. Even at a microscopic scale, no inclusion is perceptible within the matrix (Fig. 7). The bones that were recovered inside the earliest ceramic vessels from southwestern Bulgaria were thus processed as a very fine powder. The transformation of bones into powder explains why the spongy structure that is so characteristic of bone was not observed within the archaeological samples. Here again, the beige residues are clearly distinguishable from the taphonomic carbonate concretions. They show a much greater homogeneity due to the absence of sedimentary particles trapped within the matrix. They also appear much denser (Fig. 7). Chemical analysis of beige residues indicates, therefore, that the first pottery from the Balkans contained a very fine bone powder.

The FTIR spectra have allowed us to assess the degree of crystallinity for the archaeological residues, from which information was collected regarding the anthropogenic working process of bones found inside the ceramic vessels (Vieugué et al. 2009). This rate 


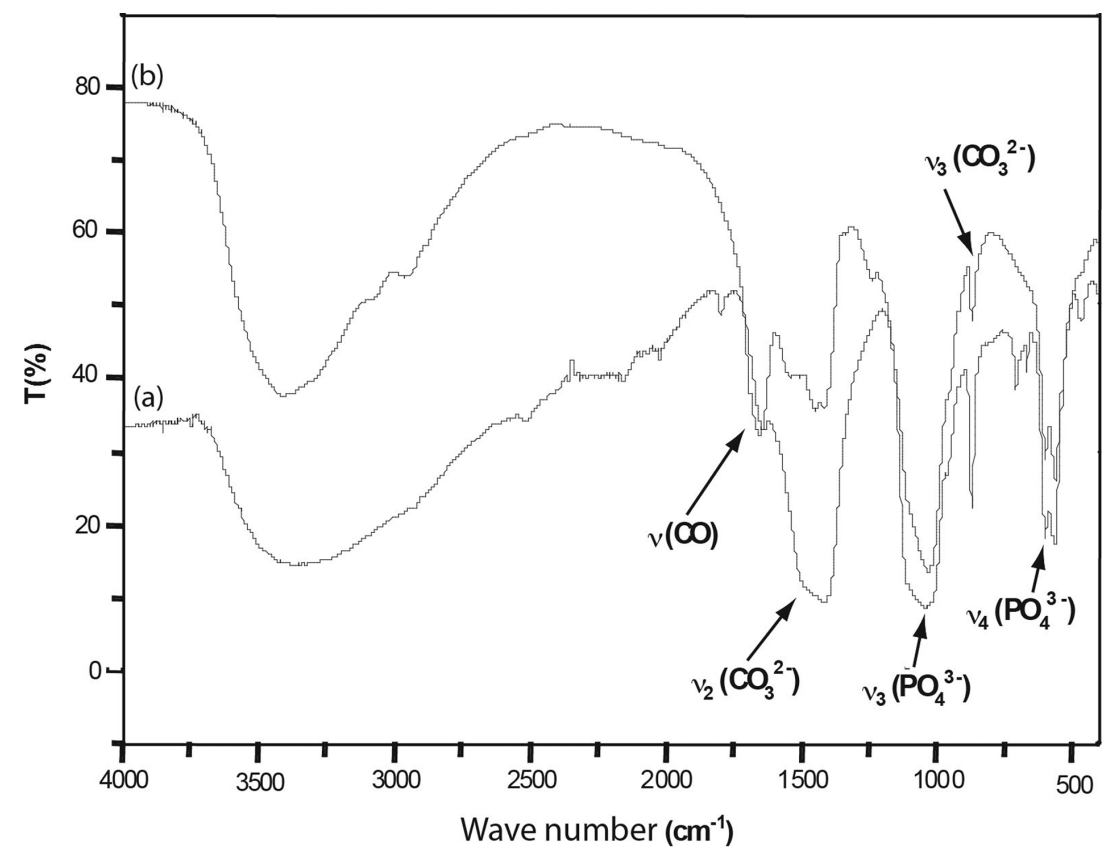

Figure 5. Comparison of infrared spectra between a beige residue (a) and a bone sample (b). $v(C O)$ around $1648 \mathrm{~cm}^{-1} ; v_{3}$ $\left(\mathrm{PO}_{4}{ }^{3-}\right)$ around $1040 \mathrm{~cm}^{-1} ; v_{3}\left(\mathrm{CO}_{3}{ }^{2-}\right)$ around $874 \mathrm{~cm}^{-1}$.
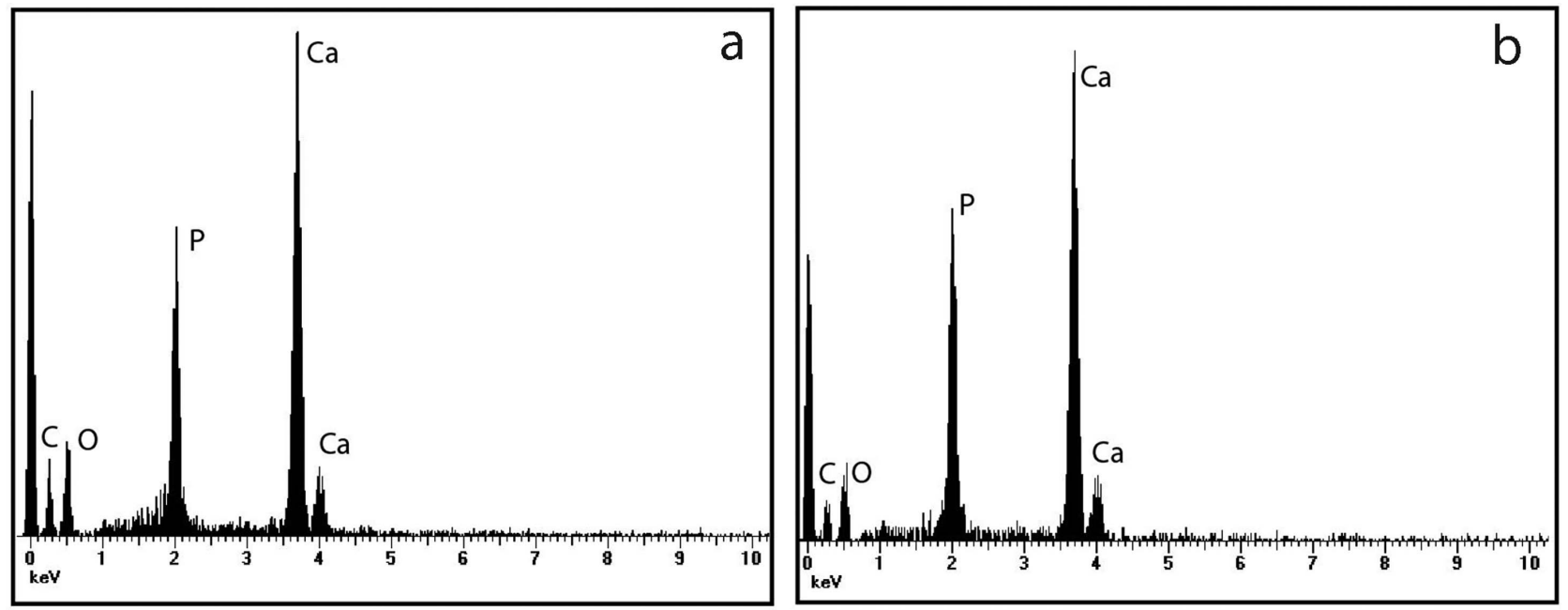

Figure 6. Comparison of SEM-EDS spectra obtained on a beige residue (a) and a bone fragment (b).

of crystallinity, estimated from the phosphate doublet using the method described by I. Reiche and collaborators (Reiche et al. 2002; 2003), is around 2.6. However, the latter is similar to that of fresh bones, which is 2.5 (Reiche et al. 2002; 2003). The bones found inside the earliest pottery from Bulgaria have, therefore, not been heated before being reduced to a very fine powder.

The absence of thermal processing of the $\mathrm{Ne}$ olithic powder, as well as its extreme fineness, shows the bones have not been reduced by grinding. The crushing of fresh bones is nearly impossible. Furthermore, micro fragments of bones would have been identified within the archaeological residues. The characteristics of bone powder preserved into the ceramic vessels are more consistent with the scraping or the abrasion of prehistoric bones. Both of these techniques do not require the preliminary heating of bones in order to reduce them to a powder. They allow, in addition, the manufacturing of a very fine bone powder which is comparable to that found inside the Neolithic ceramic vessels. 

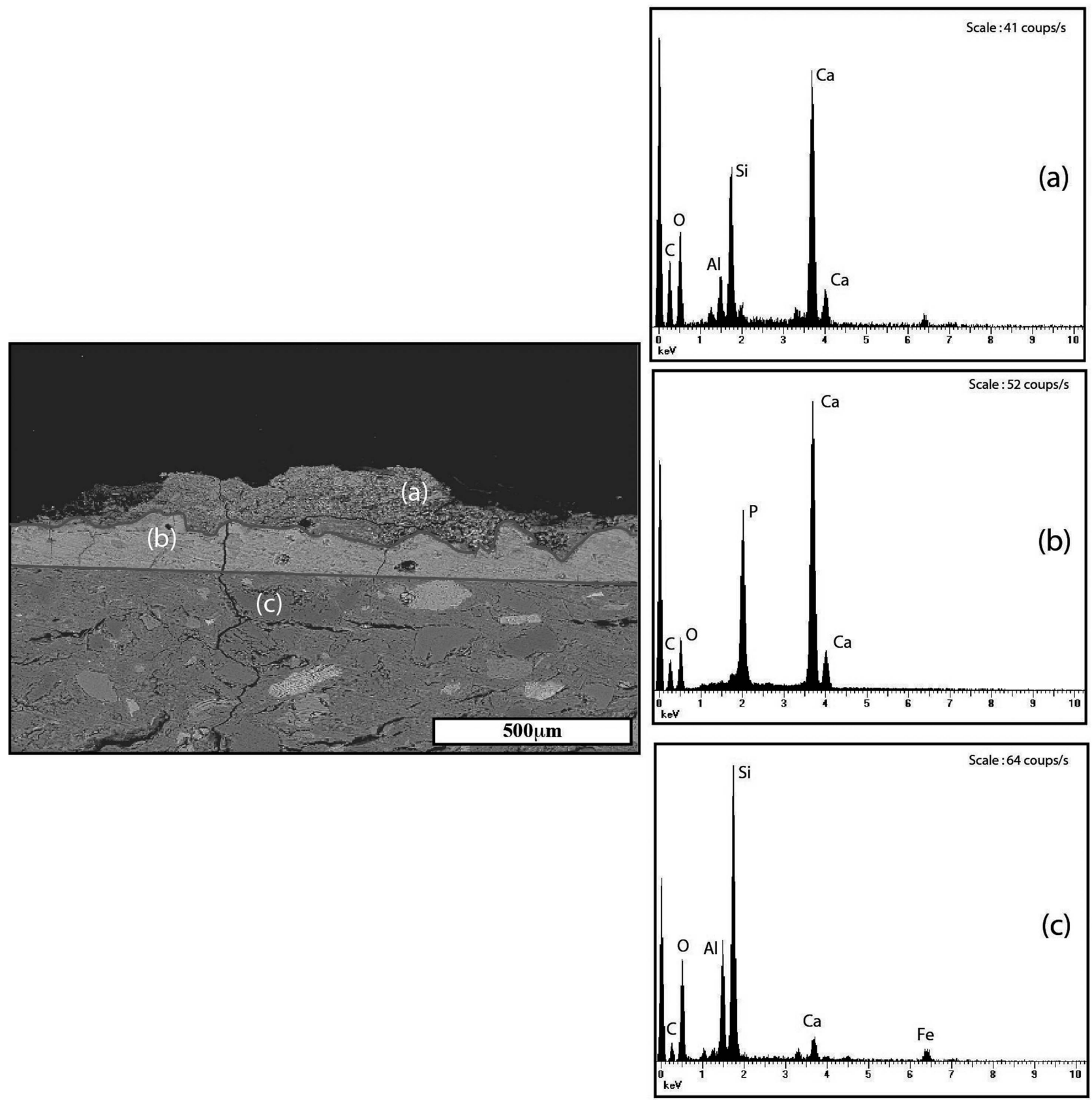

Figure 7. Back-scattered electron image and SEM-EDS spectra obtained on the post-depositional carbonate concretions (a), the beige residue (b) and the pottery sherd (c).

The vessels containing bone powder

The vessels containing bone powder present various shapes (Fig. 8). They are slightly opened or closed, with either circular or square cross-section. Their curved profile is mainly with one or two inflection points. The pottery that is associated with bone powder residues, however, demonstrates very similar dimensions. The volume of the ceramic vessels is systematically around 1.5 litres. Their wall is generally thin (4-7 mm, 33 per cent) or average (7-12 mm, 60 per cent). Their outer surfaces are usually slipped and polished (88 per cent), but exceptionally slip trailed (1 per cent). At times, they are ornamented (10 per cent), using painted (67 per cent) or incised ( 23 per cent) decoration techniques (Fig. 8). The recurrence of incised decoration is explained by the regular presence of beige residues on the inner surface of square vessels that are commonly ornamented using this technique. 

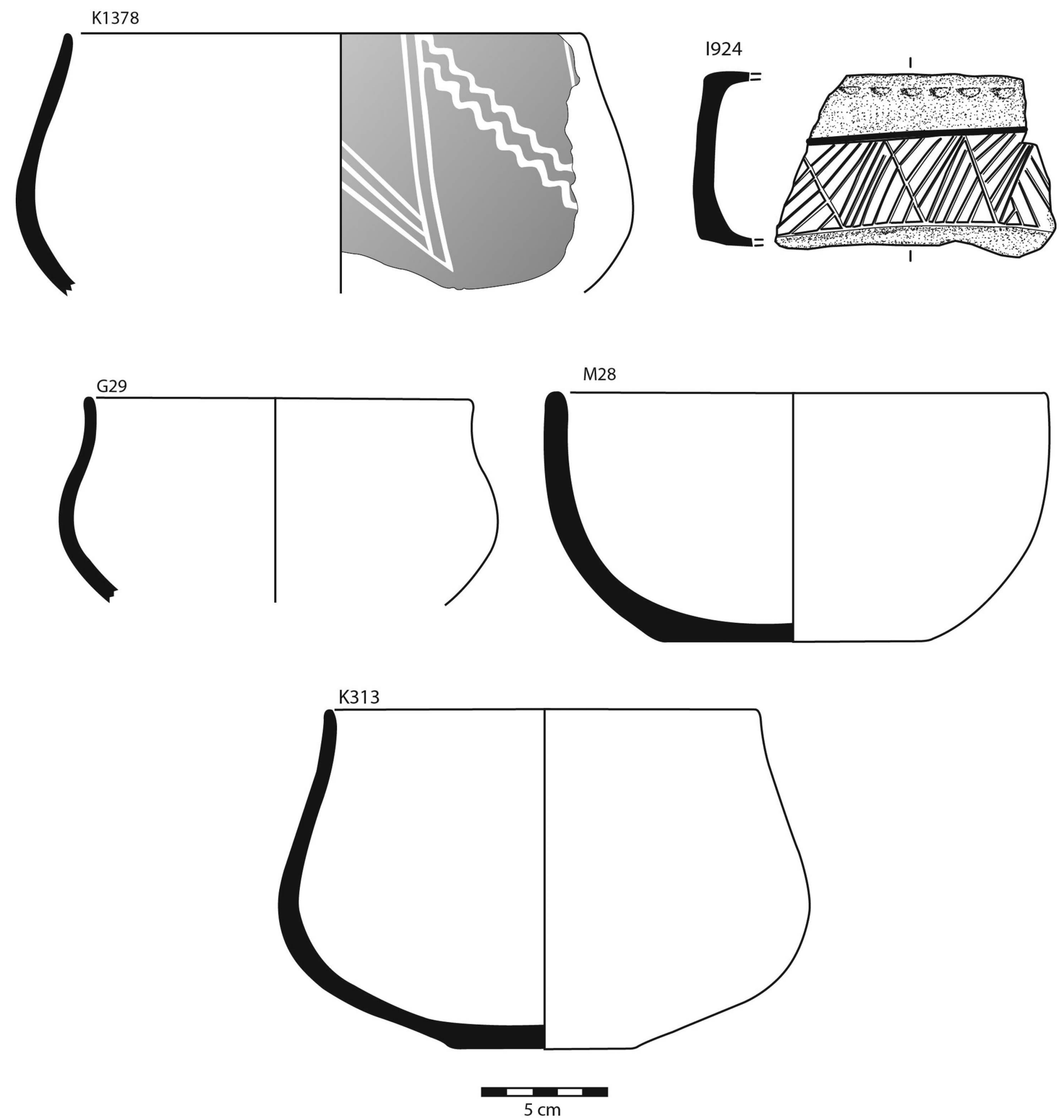

Figure 8. Example of ceramic vessels containing bone powder. (Drawing: I. Kulov.)

The ceramic vessels containing bone powder show a range of shapes, dimensions and surface treatment that is less diversified than those from the whole pottery assemblage. This finding confirms the preferential choice of a certain type of fired clay containers for the activity that involved the use of such a substance.
Interpreting the use of bone powder

The identification of bone powder in the earliest ceramic vessels from Bulgaria (6100-5600 cal. BC) immediately raised the question of the use of this raw material at the beginning of the Neolithic. The potential uses were numerous, due to its various physical properties (Vieugué 2010). The bone powder could 


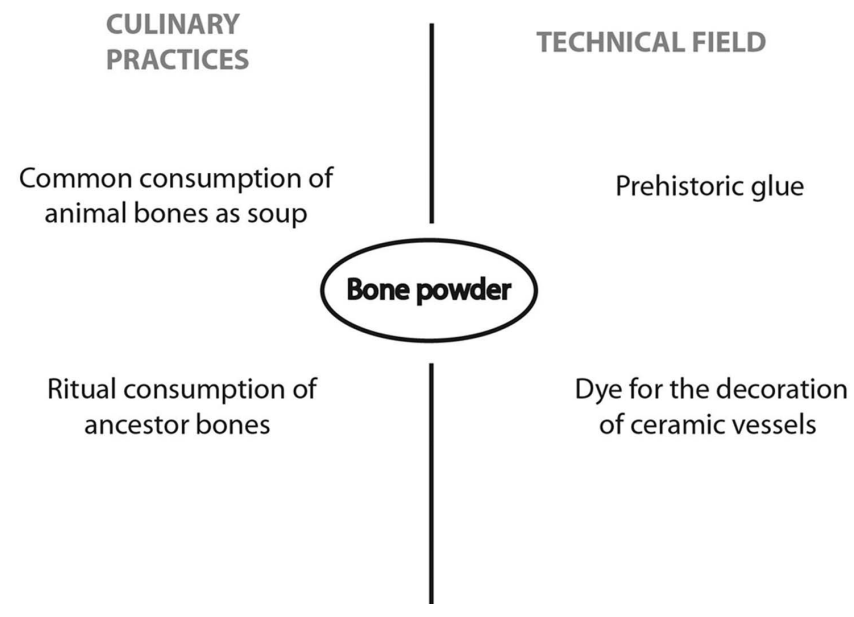

Figure 9. Potential uses of bone powder during the Neolithic.

thus have been used for several culinary or technical activities (Fig. 9). The characteristics of pottery on which the beige archaeological residues adhered have, however, allowed us to tighten the use range of bone powder within the first farming societies of Bulgaria.

The use of this raw material for technical purposes could be refuted on the basis of several pieces of evidence. The first reason is related to both the quantity and volume of the pots. If one refers to the most complete vessels, pottery that contained bone powder has systematically a capacity of about 1.5 litres. Knowing that the estimated number is about 6820 vessels at the settlement of Kovatchevo, 10,200 litres of bone powder have at least been prepared within the Neolithic village. However, such a quantity of product is much too high for the decoration of 6000 painted pottery from the site. Motifs are generally not extensive in the Early Neolithic of the Balkans (Salanova 2009). They are, furthermore, performed on medium-sized pottery. The first petrographic tests on the painted pottery from Kovatchevo confirm that the bone powder was not used for the decoration of fired clay containers; they show that the paintings were mostly made using white clay (Niellini 2006).

The second explanation is connected to the usewears of archaeological pottery. The ceramic vessels that contained bone powder do not present any sooting deposit. This absence suggests that pottery from this functional category was not used on the fire. However, heating is necessary for the production of prehistoric glues (Audry 1935; Connan 1996). Bone powder found inside the ceramic vessels could, therefore, not have been used for these activities during the Early Neolithic in the Balkans. The degree of crystallinity from archaeological beige residues confirms it. It shows that the bones were not the subjects of thermal processing (Vieugué et al. 2009).
If the bone powder has really not been used for technical purposes, then it has been used for prehistoric dietary practices. In other words, the scraped bones found inside the ceramic vessels are likely a basic ingredient for the preparation of some Neolithic dishes.

\section{Discussion: explaining the consumption of bone powder during the Early Neolithic in southwestern Bulgaria}

Chemical analyses of beige residues preserved into the earliest ceramic vessels from southwestern Bulgaria showed the presence of bone powder whose consumption was previously unexpected for the Neolithic period. On the site of Kovatchevo and Galabnik, pottery that contained such a substance comes from stratigraphic layers dated to the whole Early Neolithic sequence in southwestern Bulgaria (Salanova 2011; Salanova et al. in press). The characteristics of pottery that presented beige residues change, however, significantly over time. During the first stages (6100-5700 cal. BC), the shapes are only circular and the decorations are mainly painted. At the final stage 3, around $5700 \mathrm{cal} . \mathrm{BC}$, the incised square vessels appear beside circular shapes. The diversification of pottery shapes can testify an evolution regarding the significance of bone consumption on the Early Neolithic settlements in southwestern Bulgaria.

In addition to the possible evolution of this culinary practice, researches have shown its relative geographical extent. Bone powder was obviously consumed in the seven main Early Neolithic settlements in southwestern Bulgaria. Indeed, chemical analyses of beige residues revealed the presence of this substance within several pots of each site. This Neolithic 
dish appears, therefore, to transcend the cultural and social boundary that opposes the north and the south of the Struma valley throughout the chronological sequence (Salanova et al. in press).

Outside southwestern Bulgaria, few data are available. However, the expertise coming from other ceramic assemblages dated to the seventh and sixth millennium cal. BC in southeastern Europe leads us to think that bone powder was also consumed by the first Neolithic communities from the neighbouring regions. Indeed, identical beige residues to those that have been characterized chemically have been observed by two of us within the ceramic assemblages of several sites located in Northern Greece (Giannitsa and Nea Nikomedeia), Macedonia (Anzabegovo and Govrlevo), Central Bulgaria (Rakitovo and Karanovo) and Thessaly (Achilleion, Melissochori and Chalki). Such findings suggest that the consumption of bone powder was not an epiphenomenon that was confined to a relatively limited region in the Balkans. It was practised by all the Early Neolithic cultural entities that inhabited southeastern Europe.

The recurrent identification of bone powder within the earliest ceramic vessels from southeastern Europe raises the following question: why did the first Neolithic societies consume this type of foodstuff? Two hypotheses can be put forward, without being incompatible. The first is that the consumption of bone powder was an integral part of culinary tradition. In that case, it could be performed within the framework of the daily life of first farming societies in southwestern Bulgaria. The common consumption of animal bones is supported by several facts. In Kovatchevo, the ceramic vessels that presented beige residues refer mostly to the classical shapes. They do not concentrate in a specific area of the Neolithic village, whereas other decorated and functional pottery categories show clear concentrations in some houses (Salanova in press). They were discovered in various archaeological contexts (settlement layers, buildings, pits, etc.) and associated with the wastes from domestic activities (faunal remains, grinding tools, lithic and bone industries, etc.). Therefore all the inhabitants of the village seem to be concerned in this practice. The consumption of bones from ancestors within the framework of funeral practices cannot, however, be completely excluded. Few graves have been discovered for the beginning of the Neolithic in southwestern Bulgaria (Cochadžiev 2001; Ganetsovski 2009). Human skeletal remains have furthermore been found scattered on the site of Kovatchevo (Demoule \& Lichardus-Itten 1994), suggesting alternative funerary practices to the inhumation in tombs. The DNA analyses recently undertaken on sev- eral beige residues from the settlement of Ilindentsi by M.-F. Degouilloux and her team (PACEA, Bordeaux, France) will in particular allow us to determine the exact origin of consumed bones.

Whatever the case, the consumption of bones transcends the socio-cultural boundaries which are perceptible through the styles, manufacturing techniques and uses of ceramic vessels (Salanova et al. in press). This finding suggests that such a practice embodied more than a basic food choice.

The second assumption is that the consumption of bone powder was a response to a lack in primary dietary resources at the turn of the seventh/sixth millennium cal. BC. In many archaeological contexts, the consumption of bones or derived products (as marrow or fat) is often related to environmental and economic constraints (Vehik 1977; Binford 1981; LasotaMoskalewska et al. 1997; Outram 2004; 2005). It may also have been the case among the earliest farming communities in southwestern Bulgaria. It is possible that, as a new population arrived in the Balkans, they had a significantly constrained number of livestock at their disposal and may have had to forgo the consumption of dairy products in favour of increasing the fertility rate of the herd. Bone powder would, thus, have been consumed as a dietary substitute. The analysis of the huge faunal assemblage from Kovatchevo, led by N. Benecke and his team (Deutsches Archäologisches Institut, Berlin, Germany), should either confirm or dismiss this possibility.

The consumption of bone powder could also be linked to the degraded state of health of Neolithic populations. It could be intended for a particular category of individuals. We think of infants or the elderly. Regarding infants, we know for more recent times in history cases of early weaning of children due to unfavourable living conditions (malnutrition and illness), to overburdened women or to reproductive choice (the halt of breast-feeding reducing the gap between births and thus increasing the fertility rate of women) (Hersscher 2005). This scenario has been suggested to explain the emergence of dairy products in the Near East (Howcroft et al. 2012). It could also justify the preparation of dishes from finely powdered bones digestible by the infants insofar as this substance proves to be just as rich in calcium as milk (Leechman 1951; Lupo \& Schmitt 1997; Saint-Germain 1997). Regarding the elderly, the probable increase in life expectancy at the time of the Neolithic (BocquetAppel 2005) may lead us to imagine that new types of food preparation would have been invented in order to ease the process of consumption. This scenario could here again explain the fineness of the powder sought. Unfortunately, the scarcity of graves for the 
Early Neolithic in the southern Balkans does not currently allow for testing the validation of these two last hypotheses.

The consumption of bone powder during the Early Neolithic in the Balkans was probably caused by both cultural and nutritional factors. Future research will aim to understand the precise role of this foodstuff within the first Neolithic societies of southeastern Europe, particularly in connection with dairy products. Was the bone powder a substitute for milk, as is testified in other societies (Binford 1978). Did it replace the dairy products in a systematic or occasional way? If milk production is proved from the beginning of the Neolithic in the Near East (for example, Vigne \& Helmer 2007; Evershed et al. 2008), Anatolia (Evershed et al. 2008; Cakirlar 2012) and Central Europe (Craig et al. 2005; Salque et al. 2013), it remains very much discussed in the Balkans (Greenfield 1988; 2002 versus Vigne \& Helmer 2007). Analyses of residues trapped within ceramic vessels (Craig et al. 2005; Evershed et al. 2008; Vieugué et al. 2009; Decavallas 2011), as well as studies of faunal remains with the slaughtering age profile of main domesticated species (Greenfield \& Fowler 2005; Orton 2012), are still too scarce for answering the questions previously raised. Only the development of functional analysis of ceramic vessels combined with faunal studies seems to be able to highlight the causes for the consumption of bone powder among the first farmers of Europe.

\section{Acknowledgements}

This research has been developed within the framework of two programmes from the French Foreign Office in collaboration with Bulgaria, with the support of the French Embassy in Bulgaria, a PhD supported by the University of Paris I and the CNRS. We would like to thank J.-P. Demoule, M. Lichardus-Itten (Professors at the University of Paris 1), V. Nikolov (Researcher, National Institute of Archaeology, Sofia) and L. Perničeva ${ }^{\dagger}$ who allowed the study of ceramic assemblage from Kovatchevo. We would also like to thank Aneta Bakamska (Pernik Museum), Stefan Čochadžiev (Seint Kiril \& Methodi University, Veliko Tarnovo), Valentin Debočički (Kustendil Museum) and Veneta Genadieva (Kustendil Museum), who made available their pottery collections for comparative study in the Struma Valley.

$$
\begin{array}{r}
\text { Julien Vieugué } \\
\text { French Research Center in Jerusalem } \\
3 \text { Shimshon Street } \\
91004 \text { Jerusalem } \\
\text { Israel } \\
\text { Email: julien.vieugue@mae.u-paris10.fr }
\end{array}
$$

Laure Salanova

CNRS, UMR 7055 Préhistoire \& Technologie Maison de l'Archéologie et de l'Ethnologie 21 allée de l'Université 92023 Nanterre cedex

France

Email: laure.salanova@mae.u-paris10.fr

Martine Regert

CNRS, UMR 7264 Cultures et Environnements Préhistoire, Antiquité \& Moyen-Âge Pôle Universitaire Saint Jean d'Angély SJA 3 Avenue des Diables Bleus 06357 Nice cedex 4

France Email: martine.regert@cepam.cnrs.fr

Sigrid Mirabaud Département des Restaurateurs Institut National du Patrimoine 150 avenue du Président Wilson 93210 Saint Denis - La Plaine

France

Email: sigrid.mirabaud@inp.fr

Anne-Solenn Le Hô

Centre de Recherche et de Restauration des Musées de France

Palais du Louvre - Porte des Lions 14 Quai François Mitterrand 75001 Paris France Email: anne-solenn.leho@culture.gouv.fr

Éric Laval

Centre de Recherche et de Restauration des Musées de France

Palais du Louvre - Porte des Lions 14 Quai François Mitterrand 75001 Paris France

Email:eric.laval@culture.gouv.fr

\section{References}

Audry, P., 1935. Contribution à l'étude des propriétés de l'osséine et de la fabrication de la colle d'os. Lyon: M. Camus.

Berger, J.-F. \& J. Guilaine, 2009. The 8200 cal BP abrupt environmental change and the Neolithic transition: a Mediterranean perspective. Quaternary International 200(1-2), 33-49. 
Binford, L.R., 1978. Nunamiut Ethnoarchaeology. New York: Academic Press.

Binford, L.R., 1981. Bones: Ancient Men and Modern Myths. New York: Academic Press.

Bocquet-Appel, J.-P., 2005. La transition démographique néolithique, in Populations néolithiques et environnements. Séminaire de la chaire 'Civilisations de l'Europe au Néolithique et à l'Âge du Bronze' du Collège de France, ed. J. Guilaine. Paris: Errance, 11-20.

Cakirlar, C., 2012. Neolithic dairy technology at the European-Anatolian frontier: Implications of archaeolozoogical evidence from Ulucak Höyük, Izmir, Turkey, ca. 7000-5700 cal. BC. Anthropozoologica 47(2), 77-98.

Cauvin, J., 1997. Naissance des divinités, naissance de l'agriculture. La révolution des symboles au Néolithique (2nd edn.) Paris: Éditions CNRS.

Charters, S., R.P. Evershed, L.J. Goad \& A. Leyden, 1993. Quantification and distribution of lipid in archaeological ceramics: implications for sampling potsherds for organic residue analysis and the classification of vessel use. Archaeometry 35(2), 211-23.

Čochadžiev, S., 2001. Vaksevo. Praistoricheski selishta. Veliko Tarnovo: Faber.

Connan, J., 1996. La colle au collagène: innovation du Néolithique. La recherche 284, 33.

Copley, M.S., R. Berstan, S.N. Dudd, et al., 2005. Processing of milk products in pottery vessels through British prehistory. Antiquity 79, 895-908.

Craig, O.E., J. Chapman, C. Heron, et al., 2005. Did the first farmers of central and eastern Europe produce dairy foods? Antiquity 79, 882-94.

Craig, O.E., H. Saul, A. Lucquin et al., 2013. Earliest evidence for the use of pottery. Nature 496, 351-4.

Decavallas, O., 2007. Beeswax in Neolithic perforated sherds from the Northern Aegean: new economic and functional implications, in Cooking up the past. Food and culinary practices in the Neolithic and Bronze Age Aegean, eds. C. Mee \& J. Renard. Oxford: Oxbow, 148-57.

Decavallas, O. 2011. Étude de l'alimentation dans le mondeégéen au Néolithique et à l'Âge du Bronze à partir de l'analyse chimique de résidus organiques conservés dans les poteries. Unpublished PhD thesis, University of Bordeaux 3.

Deguilloux, M.-F., R. Leahy, M.-H. Pemonge \& S. Rottier, 2012. European Neolithization and ancient DNA: an assessment. Evolutionary Anthropology 21, 24-37.

Demoule, J.-P. \& M. Lichardus-Itten, 1994. Les fouilles franco-bulgares du site néolithique ancient de Kovatchevo: rapport préliminaire (campagne 19861993). Bulletin de Correspondance Hellénique 118(2), 561618.

Edwards, C.J., C. Ginja, J. Kantanen, L. Pérez-Parda, A. Tresset \& F. Stock, 2011. Dual origins of dairy cattle farming - evidence from a comprehensive survey of European y-chromosomal variation. PLoS One 6(1), 1-13.

Evershed, R.P., 2008. Organic residue analysis in archaeology: the archaeological biomarker revolution. Archaeometry 50(6), 895-924.
Evershed, R.P., C. Heron, S. Charters \& L.J. Goad, 1992. The survival of food residues: new methods of analysis, interpretation and application, in New developments in Archaeological Science, ed. A.M. Pollard. (Proceedings of the British Academy 77.) Oxford: Oxford University Press, 187-208.

Evershed, R.P., H.R. Mottram, S.N. Dudd, S. Charters, A.W. Stott \& G.J. Lawrence, 1997. New criteria for the identification of animal fats preserved in archaeological pottery. Naturwissenschaften 84, 402-6.

Evershed, R.P., S. Payne \& A.G. Sherratt, 2008. Earliest date for milk use in the Near East and southeastern Europe linked to cattle herding. Nature 455, 528-31.

Forenbaher, S. \& P.T. Miracle, 2005. The spread of farming in the Eastern Adriatic. Antiquity 79, 514-28.

Ganetsovski, G., 2009. Ohoden. Selishte ot rannia neolit. Razkopki 2002-2006. Sofia: Craft House.

Greenfield, H.J. 1988. The origins of milk and wool production in the old world: a zooarchaeological perspective from the Central Balkans. Current Anthropology $29,573-93$.

Greenfield, H.J. 2002. A reconsideration of the secondary products revolution in southeastern Europe: on the origins and use of domestic animals for milk, wool and traction in the Central Balkans, in The Zooarchaeology of Fats, Oils, Milk and Dairying, eds. J. Mulville \& A.K. Outram. Oxford: Oxbow, 14-31.

Greenfield, H.J. \& K.D. Fowler, 2005. The Secondary Products Revolution in Macedonia: The Zooarchaeological Remains from Megalo Nisi Galanis, a Late Neolithic-Early Bronze Age Site in Greek Macedonia. (BAR International Series 1414.) Oxford: British Archaeological Reports.

Guilaine, J. \& G. Cremonesi (eds.), 2003. Torre Sabea. Un établissement du Néolithique ancien en Salento. Rome: Ecole Française de Rome.

Helmer, D., L. Gourichon, H. Sidi Maamar \& J.-D. Vigne, 2005. L'élevage des caprinés néolithiques dans le sudest de la France: saisonnalité des abattages, relations entre grottes bergeries et sites de plein air. Anthropozoologica 40(1), 167-89.

Heron, C. \& R.P. Evershed, 1993. The analysis of organic residues and the study of pottery use. Archaeological Method and Theory 5, 247-84.

Herrscher, E., 2005. Comportements socioculturels liés à l'allaitement et au sevrage: le cas d'une population grenobloise sous l'Ancien Régime. Annales Fyssen 20, 46-66.

Horiuchi, A., N. Ochiai, H. Kurozumi \& Y. Miyata, 2011. Detection of chloride from pottery as a marker for salt: a new analytical method validated using simulated salt-making pottery and applied to Japanese ceramics. Journal of Archaeological Science 38(11), 2949-56.

Howcroft, R., G. Eriksson \& K. Lidén, 2012. The Milky Way: the implications of using animal milk products in infant feeding. Anthropozoologica 47(2), 31-43.

Jongsma, T. \& H.J. Greenfield, 2002. The household as behaviour: an anthropological perspective, in $M a$ terial evidence and culture pattern in Prehistory, ed. 
L. Nikolova. Salt Lake City (UT): International Institute of Anthropology, 1-11.

Kotova, N., 2009. The Neolithization of Northern Black Sea Area in the context of climate changes. Documenta Praehistorica 36, 159-74.

Larson, G., U. Albarella, K. Dobney, P. Rowley-Conwy, J. Schibler, A. Tresset \& J.-D. Vigne, 2007. Ancient DNA, pig domestication, and the spread of the Neolithic into Europe. Proceedings of the National Academy of Sciences 104(39), 15276-81.

Lasota-Moskalewska, A., H. Henryk, Z. Sulgostowska, J. Siemaszko \& J. Brzozowski, 1997. Animal bones as a source of calcium for mesolithic man. Przeglad Archeologiczny 45, 25-32.

Leechman, D., 1951. Bone grease. American Antiquity 4, 3556.

Lichardus-Itten, M., J.-P. Demoule, L. Perničeva, M. Grebska-Kulova \& I. Kulov, 2002. The site of Kovatchevo and the beginnings of the Neolithic period in southwestern Bulgaria. The FrenchBulgarian excavations 1986-2000, in Beiträge zu jungsteinzeitlichen Forschungen in Bulgarien, eds. M. Lichardus-Itten, J. Lichardus \& V. Nikolov. (Saarbrücker Beiträge zur Altertumskunde 74.) Bonn: Rudolf Habelt, 99-158.

Lupo, K. \& D. Schmitt, 1997. Experiments in bone boiling: nutritional returns and archaeological reflections. $A n-$ thropolozoogica 25-26, 137-44.

Marom, N. \& G. Bar-Oz, 2009. Culling profiles: the indeterminacy of archaeozoological data to survivorship curve modelling of sheep and goat herd maintenance strategies. Journal of Archaeological Science 26, 1184-7.

Martinez, R. 1993. Fonction de la céramique et régime alimentaire, in Le Néolithique au quotidien, eds. J.-C. Blanchet, A. Bulard, C. Constantin, D. Mordant \& J. Tarrète. (Actes du XVIe colloque interrégional sur le Néolithique.) Paris: Editions de la Maison des Sciences de l'Homme, 127-32.

Mirabaud, S., 2007. Développements méthodologiques en spectrométrie de masse pour l'analyse des composés organiques amorphes archéologiques. Unpublished PhD thesis, University of Lille 3.

Mirabaud, S., C. Rolando \& M. Regert, 2007. Molecular criteria for discriminating adipose fat and milk from different species by NanoESI MS and MS/MS of their triacylglycerols: application to archaeological remains. Analytical Chemistry 79, 6182-92.

Niellini, F., 2006. Céramiques et matières premières néolithiques à Kovatchevo (Bulgarie). Unpublished Master's dissertation, University of Paris I.

Outram, A.K., 2004. Identifying dietary stress in marginal environments: bone fats, optimal foraging theory and the seasonal round, in Colonisation, Migration, and Marginal Areas. A Zooarchaeological Approach, eds. M. Mondini, S. Munoz \& S. Wickler. Oxford: Oxbow 74-85.

Outram, A.K., 2005. Distinguishing bone fat exploitation from other taphonomic processes: what caused the high level of bone fragmentation at the Middle Neolithic site of Ajvide, Gotland? in The Zooarchaeology of Fats, Oils, Milk and Dairying, eds. J. Mulville \& A.K. Outram. Oxford: Oxbow, 32-43.

Orton, D., 2012. Herding, settlement, and chronology in the Balkan Neolithic. European Journal of Archaeology 15(1), 5-40.

Perlès, C., 2001. The Early Neolithic in Greece. The First Farming Communities in Europe. Cambridge: Cambridge University Press.

Regert, M., 1998. Du terrain au laboratoire: récolte, stockage, analyses chimiques et potentiel informatif de matériaux organiques témoignant de diverses activités techniques et alimentaires. Adhésifs d'emmanchement, résidus carbonisés conservés dans des céramiques. Internéo 2, 5-16.

Regert, M. 2007. Elucidating pottery function using a Multistep Analytical Methodology combining Infrared Spectroscopy, Chromatographic Procedures and Mass Spectrometry, in Theory and Practice of Archaeological Residue Analysis, eds. H. Barnard \& J.W. Eerkens. (BAR International Series 1650.) Oxford: Archaeopress, 6176.

Regert, M., S. Colinart, L. Degrand \& O. Decavallas, 2001. Chemical alteration and use of beeswax through time: accelerated ageing tests and analysis of archaeological samples from various environmental contexts. Archaeometry 43(4), 549-79.

Regert, M., S.N. Dudd, P. Petrequin \& R.P. Evershed, 1999. Fonction des céramiques et alimentation au Néolithique final sur les sites de Chalain. De nouvelles voies d'étude fondées sur l'analyse chimique des résidus organiques conservés dans les poteries. Revue d'Archéométrie 23, 91-9.

Regert, M., M.-F. Guerra \& I. Reiche, 2006a. Physico-chimie des matériaux du patrimoine culturel - Partie 1. Techniques de l'Ingénieur P 3780, 1-21.

Regert, M., M.-F. Guerra \& I. Reiche, 2006b. Physico-chimie des matériaux du patrimoine culturel - Partie 2. Techniques de l'Ingénieur P 3781, 1-11.

Regert, M., S. Mirabaud, P. Petrequin, A.-M. Petrequin \& C. Rolando, 2008. Mise en place de nouvelles stratégies analytiques pour la sauvegarde des informations chimiques conservées dans des céramiques archéologiques. Technè (special issue, ed. S. Colinart), 24-35.

Reiche, I., L. Favre-Quattropani, C. Vignaud, H. Bocherens, L. Charlet \& M. Menu, 2003. A multi-analytical study of bone diagenesis: the Neolithic site of Bercy (Paris, France). Measurement Science and Technology 14, 160819.

Reiche, I., C. Vignaud \& M. Menu, 2002. The crystallinity of ancient bone and dentine: new insights by transmission electron microscopy. Archaeometry 44(3), 447-59.

Reingruber, A. \& L. Thissen, 2005. 14C database for the Aegean catchment (Eastern Greece, Southern Balkans and Western Turkey) 10,000-5500 cal. BC, in How did farming reach Europe? Anatolian-European relations from 
the second half of the 7th through the first half of the 6th millennium cal. BC, ed. C. Lichter. (BYZAS 2.) Istanbul: Ege Yayinlari, 295-327.

Saint-Germain, G., 1997. The production of bone broth: a nutritional exploitation. Anthropolozoogica 25-26, 1536.

Salanova, L., 2009. La plus ancienne céramique bulgare (Kovatchevo, Bulgarie): caractérisation technique, implications socio-culturelles, in Méthodes d'approches des premières productions céramiques: les Balkans et le Levant Nord, eds. L. Astruc, A. Gaulon \& L. Salanova. (Internationale Archäologie 12.) Rahden/Westf., 21-8.

Salanova, L., 2011. Ceramic assemblages and chronology: problems and solutions for the Early Neolithic Settlement of Kovatchevo. Studia Praehistorica 14, 286-98.

Salanova, L., in press. Les premières communautés agropastorales de Bulgarie (7e-6e millénaires av. J.-C.). Des productions matérielles aux societés humaines. Comptes-rendus de l'Académie des Inscriptions et BellesLettres.

Salanova, L., L. Gomart \& J. Vieugué, in press. 6000 BC in Southwest Bulgaria: diversity and discontinuities during the Neolithization process, in Times of Change: The Turn from the 7th to the 6 th Millennium BC in the Near East and Southeast Europe, eds. P. Biehl \& E. Rosenstock. Cambridge: Cambridge University Press.

Salanova, L., J. Vieugué \& L. Gomart, 2010. Методика на изследване на големи керамични комплекси: сериация на неолитната керамика от Ковачево (България). Arheologia (Sofia), 7-23.

Salque, M., G. Radi, A. Tagliacozzo, et al., 2012. New insights into the Early Neolithic economy and management of animals in Southern and Central Europe revealed using lipid residue analyses of pottery vessels. Anthropozoologica 47(2), 46-61.

Salque, M., P.I. Bogucki, J. Pyzel, I. Sobkowiak-Tabaka, R. Grygiel, M. Szmyt \& R.P. Evershed, 2013. Earliest evidence for cheese making in the sixth millennium BC in northern Europe. Nature 493, 522-5.

Skibo, J.-M., 1992. Pottery Function. A Use-alteration Perspective. New York: Springer.

Skibo, J.-M. \& E. Blinman. 1999. Exploring the origins of pottery on the Colorado plateau, in Pottery and People. A Dynamic Interaction, eds. J.M. Skibo \& G.M. Feinman. Salt Lake City (UT): University of Utah Press, 171-83.

Testart, A., 1982. Les chasseurs-cueilleurs ou l'origine des inégalités. Paris: Société d'Ethnographie.

Tiné, V., 2009. Favella. Un villaggio neolitico nella Sibaritide, Studi di Paletnologia Italiana. Rome: Instituto Poligrafico e Zecca dello Stato.

Tresset, A., R. Bollongino, J.C. Edwards, S. Hughes \& J.-D. Vigne, 2009. Early diffusion of domestic bovids in Europe. An indicator for human contacts, exchanges and migrations? In Becoming Eloquent, eds. F. d'Errico \& J.-M. Hombert. Amsterdam: John Benjamins, 69-90.

Vehik, S.C., 1977. Bone fragments and bone grease manufacturing: a review of their archaeological use and potential. Plains Anthropologist 22(77), 169-82.
Vieugué, J., 2010. Du vase aux tessons: formes et fonctions de la céramique du Néolithique ancien de l'habitat de Kovatchevo (6100-5500 av. J.-C., Bulgarie). Unpublished PhD, University of Paris I.

Vieugué, J., 2014. Fonction des contenants et des outils en céramique: les premières productions de Bulgarie (6ème millénaire av. J.-C.). Paris: Éditions CNRS.

Vieugué, J., forthcoming. Early Neolithic pottery shapes and functions in the Struma Valley: chronological and regional variations, in The Neolithic transition in Bulgaria, eds. M. Grebska-Kulova \& L. Salanova.

Vieugué, J., S. Mirabaud \& M. Regert, 2008. Contribution méthodologique à l'analyse fonctionnelle des céramiques d'un habitat néolithique : l'exemple de Kovatchevo (6200-5500 av. J.-C.). Archéosciences 32, 99-114.

Vieugué, J., S. Mirabaud, V. Wright, C. Chadefaux \& M. Regert, 2009. Bone powder and animal fats contained in the ceramic vessels from the earliest Neolithic site of Bulgaria, Kovatchevo (6200-5500 B.C.), in Méthodes d'approches des premières productions céramiques: les Balkans et le Levant Nord, eds. L. Astruc, A. Gaulon \& L. Salanova. (Internationale Archäologie 12.) Rahden/Westf., 29-38.

Vigne, J.-D., 2003. L'exploitation des animaux à Torre Sabea : nouvelles analyses sur les débuts de l'élevage en Méditerranée centrale et occidentale, in Torre Sabea: un établissement du Néolithique ancien en Salento, eds. J. Guilaine \& G. Cremonesi. Rome: Ecole Française de Rome, 325-59.

Vigne, J.-D., 2008. Zooarchaeological aspects of the Neolithic diet transition in the Near East and Europe, and their putative relationships with the Neolithic demographic transition, in The Neolithic transition and its consequences, eds. J.-P. Bocquet Appel \& O. Bar-Yosef. New York: Springer, 179-205.

Vigne, J.-D. \& D. Helmer, 2007. Was milk a 'secondary product' in the Old World Neolithisation process? Its role in the domestication of cattle, sheep and goats. $A n$ thropozoologica 42(2), 9-40.

Watkins, T., 1992. The beginning of the Neolithic: searching for meaning in material culture change. Paléorient 18(1), 63-75.

Weller, O. 2000. Les premières formes d'exploitation du sel durant le Néolithique et le Chalcolithique européen: de la reconnaissance des techniques à l'analyse des dimensions socio-économiques. Unpublished $\mathrm{PhD}$, University of Paris I.

\section{Author biographies}

Julien Vieugué has developed a multidisciplinary approach for the function of prehistoric pottery which combines typometric characteristics (shape, size, volume) and use-wears (residues and attritions). In the framework of a $\mathrm{PhD}$, he applied this new method to the huge pottery assemblage from Kovatchevo (6100-5600 cal. BC, Bulgaria), in order to 
determine the role of ceramic vessels within the Earliest Neolithic communities from the Balkans. His researches are now extending to the whole Mediterranean Basin, in order to understand the factors that led to the adoption of pottery production in the region.

Laure Salanova's researches are focused on social and cultural aspects of pottery during late prehistory, mainly during the transitions at the beginning and the end of the Neolithic period. She has supervised the analysis of the pottery assemblage from the Early Neolithic settlements of Kovatchevo (Bulgaria) and has conducted other projects in Bulgaria since 2002. She is currently studying other assemblages in Europe and Africa in order to understand the role of the pottery during periods of historical change.

Martine Regert is a specialist in biomolecular archaeology. Her research is in three main domains: (i) developing new micro- or non-destructive analytical methodologies for the identification of amorphous organic materials, namely waxes, resins, wine residues, culinary commodities, adhesives, etc. preserved in archaeological contexts or in any object from our cultural heritage; (ii) understanding pottery function by using residue analyses; (iii) determining the strategies of procurement, production and use of natural organic substances by our ancestors from prehistoric times until recent periods.
Sigrid Mirabaud has a PhD in analytical chemistry. After some years at the C2RMF (Centre de Recherche et de Restauration des Musées de France, Louvre, Paris, France), as a conservation scientist, where she was in charge of the analysis of easel paintings, she is now head of the laboratory at the National Institute of Cultural Heritage (Institut national du patrimoine, Paris, France). Her research focuses on materials as markers of human activity, especially organic materials. She leads a research project on materials and techniques of Ethiopian paintings.

Anne-Solenn Le Hô is a conservation scientist at the Centre de Recherche et de Restauration des Musées de France (C2RMF) in Paris. She is in charge of analysis of paintings and painted objects focused on the technical analysis of works of art, research into their deterioration and authentification. She is an expert in vibrational techniques (infrared and Raman). She is working on a number of different projects including the chemistry, manufacture and uses of archaeological natural substances.

Éric Laval is a research engineer at the C2RMF (Centre de Recherche et de Restauration des Musées de France, Louvre, Paris, France). He is in charge of scanning electron microscopy and X-ray fluorescence. His work is about the study and characterization of raw materials used for the manufacture of archaeological and art objects. 